The Canadian Mineralogist

Vol. 39, pp. 761-768 (2001)

\title{
BIGCREEKITE: A NEW BARIUM SILICATE MINERAL SPECIES FROM FRESNO COUNTY, CALIFORNIA
}

\author{
LAUREL C. BASCIANO AND LEE A. GROAT ${ }^{\S}$ \\ Department of Earth and Ocean Sciences, University of British Columbia, Vancouver, British Columbia V6T 1Z4, Canada
}

ANDREW C. ROBERTS

Geological Survey of Canada, 601 Booth Street, Ottawa, Ontario K1A OE8, Canada

ROBERT A. GAULT

Research Division, Canadian Museum of Nature, P.O. Box 3443, Station D, Ottawa, Ontario K1P 6P4, Canada

GAIL E. DUNNING

773 Durshire Way, Sunnyvale, California 94087, U.S.A.

ROBERT E. WALSTROM

P.O. Box 1728, Silver City, New Mexico 88062, U.S.A.

\begin{abstract}
The sanbornite deposits at Big Creek and Rush Creek, Fresno County, California, are host to many rare barium silicates. Bigcreekite, ideally $\mathrm{BaSi}_{2} \mathrm{O}_{5} \bullet 4 \mathrm{H}_{2} \mathrm{O}$, is a newly identified mineral species that occurs along very thin transverse fractures in laminated quartz-rich sanbornite portions of the rock. It postdates the other associated barium silicates and represents either a later primary phase from infiltrated fluids or a product of alteration of pre-existing Ba-rich minerals, possibly sanbornite. It is white to colorless and forms poorly developed crystalline masses parallel to the fracture direction. There are two perfect cleavages, $\{010\}$ and $\{001\}$. Other physical properties are: tabular habit, elongate [100], brittle, non-fluorescent, vitreous to pearly luster, white streak, H 2-3, uneven fracture. Bigcreekite is biaxial positive, $\alpha 1.537(2), \beta 1.538(2), \gamma 1.541(2) ; X=b, Y=a, Z=c, 2 V_{\text {meas }}$ $59.2(5)^{\circ}, 2 V_{\text {calc }} 60^{\circ}$; dispersion is moderate, $r<v$, and it is non-pleochroic. It is orthorhombic, space group Pnma, with unit-cell parameters refined from powder data: $a$ 5.038(6), $b 9.024(3), c$ 18.321(6) $\AA, V 833(1) \AA^{3}, Z=4$. The strongest six lines of the $\mathrm{X}$ ray powder-diffraction pattern $[d$ in $\AA(I)(h k l)]$ are: 5.068(100)(013), 4.054(85)(022), 2.974(45)(031), 2.706(60)(124), 2.327(40)(035) and 2.257(75)(126). The empirical formula of bigcreekite (based on $\mathrm{O}=9$ ) is $\left(\mathrm{Ba}_{1.00} \mathrm{Na}_{0.01}\right)_{\Sigma 1.01} \mathrm{Si}_{2.00} \mathrm{H}_{8.00} \mathrm{O}_{9.00}$. $D_{\text {calc }}=2.76 \mathrm{~g} / \mathrm{cm}^{3}$, and $D_{\text {meas }}=2.66(3) \mathrm{g} / \mathrm{cm}^{3}$. The structure has been refined to $R=3.5 \%$. Bigcreekite is a hydrous inosilicate; the $\mathrm{SiO}_{4}$ tetrahedra are arranged in four-membered rings that form chains parallel to [100] and are staggered in the [001] direction. Molecules of $\mathrm{H}_{2} \mathrm{O}$ fill the large spaces between the rows of silicate tetrahedra. The structure of bigcreekite has similarities to those of both sanbornite and gillespite. Bigcreekite was named after Big Creek, California, the type locality.
\end{abstract}

Keywords: bigcreekite, new mineral species, barium silicate tetrahydrate, crystal structure, inosilicate, Big Creek, California.

SOMMAIRE

Les gisements de sanbornite situés le long des ruisseaux Big Creek et Rush Creek, comté de Fresno, en Californie, renferment plusieurs silicates de barium rares. Bigcreekite, dont la composition idéale est $\mathrm{BaSi}_{2} \mathrm{O}_{5} \bullet 4 \mathrm{H}_{2} \mathrm{O}$, est une nouvelle espèce minérale qui tapisse les fractures transversales très minces d'une roche riche en sanbornite à laminations de quartz. Elle est donc tardive par rapport aux autres silicates de barium, et représenterait soit une phase primaire formée à partir de fluides infiltrés, soit un produit d'altération des minéraux de barium pré-existants, la sanbornite peut-être. Elle est blanche à incolore et se présente en amas cristallins peu développés parallèles au plan de fracture. Il y a deux clivages parfaits, $\{010\}$ et $\{001\}$. Les cristaux forment des plaquettes tabulaires, allongées selon [100]; ils sont cassants, à éclat vitreux ou nacré, sans fluorescence, à rayure blanche, de dureté $2-3$, et à cassure inégale. La bigcreekite est biaxe positive, $\alpha 1.537(2), \beta 1.538(2), \gamma 1.541(2) ; X=b, Y=a, Z=c, 2 V_{\text {mes }}$

$\S \quad$ E-mail address: 1groat@eos.ubc.ca 
$59.2(5)^{\circ}, 2 V_{\text {calc }} 60^{\circ}$; sa dispersion est modérée, $r<v$, et elle est non pléochrö̈que. Il s'agit d'un minéral orthorhombique, groupe spatial Pnma, avec les paramètres réticulaires suivants, affinés à partir des données sur poudre: $a$ 5.038(6), $b$ 9.024(3), $c$ 18.321(6) $\AA, V$ 833(1) $\AA^{3}, Z=4$. Les six raies les plus intenses du spectre de diffraction $[d$ en $\AA(I)(h k l)]$ sont: 5.068(100)(013), 4.054(85)(022), 2.974(45)(031), 2.706(60)(124), 2.327(40)(035) et 2.257(75)(126). La formule empirique de la bigcreekite (calculée sur une base de neuf atomes d'oxygène) est $\left(\mathrm{Ba}_{1.00} \mathrm{Na}_{0.01}\right)_{\Sigma 1.01} \mathrm{Si}_{2.00} \mathrm{H}_{8.00} \mathrm{O}_{9.00} . D_{\text {calc }}=2.76 \mathrm{~g} / \mathrm{cm}^{3}$, et $D_{\text {mes }}=2.66(3) \mathrm{g} /$ $\mathrm{cm}^{3}$. La structure a été affinée jusqu'à un résidu $R$ de $3.5 \%$. La bigcreekite est un inosilicate hydraté; les tétraèdres $\mathrm{SiO}_{4}$ sont agencés en anneaux à quatre membres formant des chaînes parallèles à [100] qui sont décalées dans la direction [001]. Des molécules de $\mathrm{H}_{2} \mathrm{O}$ remplissent les espaces entre les rangées de tétraèdres. La structure de la bigcreekite ressemble à celle de la sanbornite et de la gillespite. Son nom provient du nom de la localité-type, Big Creek, en Californie.

(Traduit par la Rédaction)

Mots-clés: bigcreekite, nouvelle espèce minérale, silicate de barium tétrahydraté, structure cristalline, inosilicate, Big Creek, Californie.

\section{INTRODUCTION}

Bigcreekite was discovered by one of us (REW) in 1980, from blast rock associated with construction of National Forest Route 9, along the west side of Big Creek in eastern Fresno County, California. The rock occurs on the Esquire \#7 claim (Section 27, T11S, R25E, Mount Diablo Meridian, lat. 36 $55^{\prime} \mathrm{W}$, long. $\left.119^{\circ} 14^{\prime} 42^{\prime \prime} \mathrm{N}\right)$. Considered a rare species, bigcreekite fills very thin $(<0.5 \mathrm{~mm})$ transverse fractures in gneissic rocks composed of variable amounts of sanbornite and quartz (Fig. 1), with minor amounts of diopside, pyrrhotite and barium-bearing minerals. The rocks form conformable tabular bodies up to $13 \mathrm{~m}$ thick within foliated quartzite at or within $100 \mathrm{~m}$ of the contact with a granodiorite pluton. The Big Creek site is the type lo-

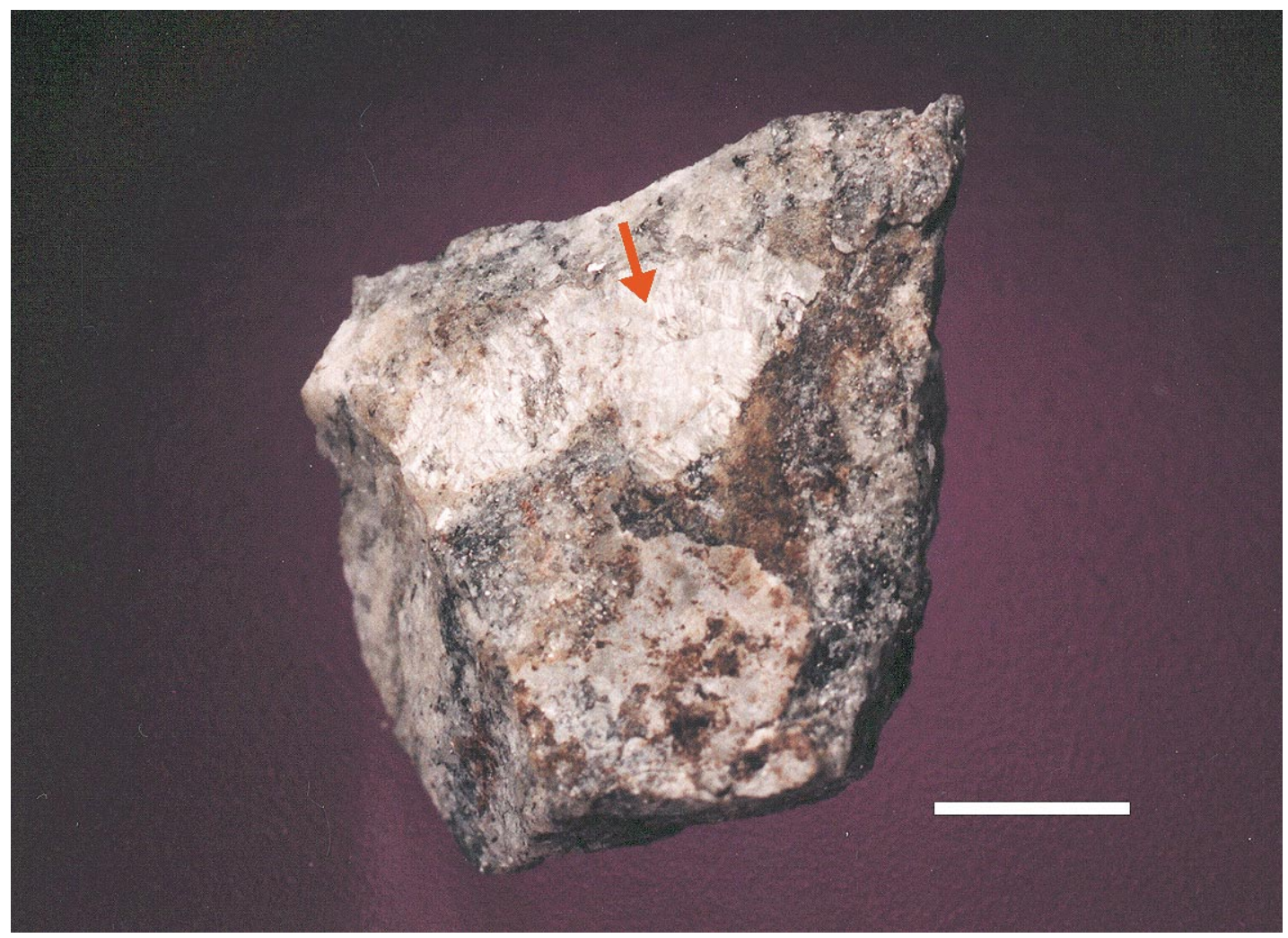

FIG. 1. Vein of bigcreekite (arrow) in quartz-sanbornite rock. Scale bar: $1 \mathrm{~cm}$. 
cality for alforsite and walstromite and is known for several rare minerals including anandite, bazirite, benitoite, celsian, gillespite, fresnoite, muirite, macdonaldite, pellyite, titantaramellite, and verplanckite (Alfors et al. 1965, Alfors \& Pabst 1984). Additional minerals currently under study include UKBC-10, a $\mathrm{Ba}-\mathrm{Fe}-\mathrm{Al}-\mathrm{Cl}$ silicate, UKBC-27, a Ba-Fe-Ca-Mn silicate-phosphate, and UKBC-39a and b, the $\mathrm{Fe}-\mathrm{Cl}$ analogues of ericssonite and orthoericssonite, respectively.

Bigcreekite also has been found filling thin fractures in barium silicate lenses exposed along the northwestern slope of Trumbull Peak, Mariposa County, California (NE1/4 Section 9, T3S, R19E, Mount Diablo Meridian). The Trumbull Peak barium silicate site is the type locality for sanbornite and is known for several rare minerals including alforsite, celsian, gillespite, macdonaldite, pellyite, titantaramellite, and witherite (Dunning \& Copper 1999). Additional minerals recently identified from these Ba-rich lenses include benitoite, fresnoite, kinoshitalite, walstromite, and several new Ba-silicate minerals which are currently under study, including UKBC-10, UKRC-21 (hydrous silica), UKBC-27, UKBC-39a and b, and UKTP-1, a Ba-Fe$\mathrm{Cl}$ silicate-carbonate.

At both localities, bigcreekite formed during or after the fracturing of the barium silicate rocks. It postdates the host rock, and may represent either a later primary phase deposited from infiltrating fluids or a product of alteration of a pre-existing Ba-rich mineral, possibly sanbornite. The barium silicate rocks probably originated from Paleozoic sedimentary units that were metamorphosed prior to being uplifted to their present position. The mineral assemblages in these rocks are probably related to the initial bulk composition of the sedimentary rocks prior to metamorphism. Hinthorne (1974) suggested that sanbornite was formed by the reaction of witherite with quartz, and that the sanbornitequartz rocks formed at temperatures between 440 and $600^{\circ} \mathrm{C}$.

Bigcreekite is named after the type locality. The mineral and mineral name have been approved by the Commission on New Minerals and Mineral Names, IMA. Cotype material is housed in the M.Y. Williams Museum at the University of British Columbia, Vancouver, British Columbia.

\section{Physical and Optical Properties}

Bigcreekite occurs as subhedral crystalline masses, millimeters in length, parallel to the fracture direction of the rock. There are two perfect cleavages, $\{010\}$ and $\{001\}$. It has a tabular habit, elongate on [100]. The cleavable masses are brittle, white to colorless, nonfluorescent, with vitreous to pearly luster, a white streak, and an uneven fracture. Bigcreekite has an approximate hardness of 2 to 3 . The density, 2.66(3) $\mathrm{g} / \mathrm{cm}^{3}$, was measured by suspension in bromoform, and is slightly lower than the calculated density of $2.76 \mathrm{~g} / \mathrm{cm}^{3}$; this difference is most likely due to the small size of the crystals and the perfect cleavages, which results in air being trapped on surfaces and within the crystals.

Bigcreekite is biaxial positive, with the indices of refraction $\alpha 1.537(2), \beta 1.538(2), \gamma 1.541(2)(590 \mathrm{~nm})$; $2 V_{\text {meas }}=59.2(5)^{\circ}, 2 V_{\text {calc }}=60^{\circ}$; dispersion is moderate, $r<v$, and the mineral is non-pleochroic. The optical orientation is $X=b, Y=a, Z=c$. Application of the Gladstone-Dale relationship (Mandarino 1981) gives a compatibility index of -0.013 , which is considered superior. The unit-cell parameters, refined using X-ray powder-diffraction data (Table 1) and starting values from the crystal-structure study, are $a$ 5.038(6), $b$ 9.024(3), $c$ 18.321(6) $\AA, V$ 833(1) $\AA^{3}$, with $a: b: c=$ $0.5583: 1: 2.0303$.

\section{Chemical Composition}

Chemical analyses were performed with a JEOL 733 electron microprobe using Tracor Northern 5500 and 5600 automation, operating in the wavelength-dispersion mode. Data reduction was done with a conventional ZAF routine in the Tracor Northern TASK series of programs. Chemical analyses were performed with the

TAELE 1. X-RAY FOWDER-DIFFRACTION DATA FOR BIGCREEKITE

\begin{tabular}{|c|c|c|c|c|c|c|c|}
\hline sex & $\sigma_{N \in+1}$ & $\phi_{3 \mathrm{a}}$ & $h d$ & $I_{0}$ & $\phi_{\text {metr }}$ & $d_{c s s}$ & Hat \\
\hline 30 & 9.189 & 9.161 & 002 & 40 & 1.845 & 1.847 & 119 \\
\hline 100 & 5060 & 5056 & 013 & 3 & 7.816 & 1.615 & 048 \\
\hline 3 & 4.861 & 4.858 & 101 & 20 & 1.732 & 1.731 & 053 \\
\hline 20 & 4.575 & 4.5BO & 004 & 3 & 7.700 & 1.709 & 235 \\
\hline 30 & 4419 & 4.414 & 102 & & & 1. 707 & 140 \\
\hline 20 & 4.255 & 4.277 & 111 & 20 & 1.B55 & 1.690 & 0210 \\
\hline 85 & 4054 & 4048 & 022 & & & 1.695 & $2 \overline{03}$ \\
\hline 5 & 3875 & 3.886 & 103 & & & 1.692 & 151 \\
\hline-30 & 3.572 & 3.569 & 113 & 今 & 1.䄪句 & 1.665 & 213 \\
\hline 40 & 3,399 & 3.395 & 015 & 25 & 1.637 & 1.630 & 0111 \\
\hline 3 & 3299 & 3305 & 121 & & & 1.637 & 153 \\
\hline 3 & 3200 & 3,214 & 024 & 3 & 7.620 & 1.619 & 303 \\
\hline 5 & 3.153 & 31.55 & 122 & 3 & 1.904 & 1.599 & 139 \\
\hline-15 & 3056 & 3.054 & 006 & 3 & 1.576 & 1.5885 & 228 \\
\hline 45 & 2.974 & $2.96 \mathrm{~s}$ & 031 & & & 1.589 & 321 \\
\hline 10 & 2.014 & 2.815 & 115 & $=10$ & 1.557 & 1.550 & 111 \\
\hline Q & 2.700 & 2.710 & 124 & 3 & 7.540 & 1.541 & 155 \\
\hline 20 & 2.614 & 2611 & 106 & 15 & 1.525 & $1.52 \theta$ & 245 \\
\hline 5 & 2.559 & 2.557 & 131 & & & 1.527 & 0012 \\
\hline \multirow[t]{2}{*}{30} & 2.512 & 2.519 & 200 & & & 1.527 & 305 \\
\hline & & 2508 & 116 & -10 & 1.503 & 1.504 & 060 \\
\hline 5 & 2,430 & 2428 & 210 & 10 & 7.485 & 1.499 & $32 d$ \\
\hline 40 & 2.327 & 2325 & 085 & & & 1.485 & 150 \\
\hline 10 & 2,291 & 2290 & 000 & 3 & 1.460 & 1.467 & 250 \\
\hline 75 & 2.257 & 2260 & 126 & & & 1.452 & 316 \\
\hline 20 & 2,194 & 2.191 & 042 & 5 & 1.446 & 1.449 & 149 \\
\hline 5 & 2.133 & 2.139 & 222 & 25 & 1.424 & 1,425 & 157 \\
\hline .10 & 2070 & 2069 & 223 & & & 142 & 0410 \\
\hline 25 & 2.042 & 2.042 & 028 & 3 & 1,399 & 1.397 & $3 \overline{34}$ \\
\hline 5 & 2010 & 2.009 & 142 & -20 & 1.391 & 1.390 & 1212 \\
\hline 15 & 1.974 & 1.975 & 037 & 3 & 1.373 & 1.373 & 2111 \\
\hline \multirow[t]{2}{*}{$3 \mathrm{~b}$} & 1.928 & 1.931 & 230 & 3 & 1348 & 1. 949 & 327 \\
\hline & & 1.921 & 231 & 3 & 1.328 & 1.329 & 2310 \\
\hline \multirow[t]{3}{*}{25} & 1.804 & 1.800 & 232 & 30 & 1.304 & 1304 & 159 \\
\hline & & 1.887 & 109 & & & 1.303 & 100 \\
\hline & & 1.879 & 144 & & & & \\
\hline
\end{tabular}

Note: Daka collected using a $714.6-m$ m Debye-Scherfer powder camera, Cu

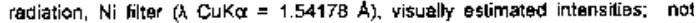
bortected for sh:nnkage and no Internal standard; indexed with a 5.038, $b$, 9.024 , C 18,324 A. * Reflections used for unit-cenl tefingment $\mathrm{b}=\mathrm{b}$. 
following operating conditions: excitation voltage 15 $\mathrm{kV}$, beam current $20 \mathrm{nA}$, peak count time $20 \mathrm{~s}$, background count time $10 \mathrm{~s}$, and beam diameter $5 \mu \mathrm{m}$. For the elements recorded, the following standards and Xray lines were used: albite $(\mathrm{NaK} \alpha)$, sanbornite $(\mathrm{Si} K \alpha$, $\mathrm{Ba} L \alpha)$, diopside $(\mathrm{Ca} K \alpha)$, and celestine $(\mathrm{Sr} L \alpha)$. F and $\mathrm{Na}$ were sought but not detected. Based on nine oxygen atoms per formula unit, the empirical formula $\left(\mathrm{Ba}_{1.00}\right.$ $\left.\mathrm{Na}_{0.01}\right)_{\Sigma 1.01} \mathrm{Si}_{2.00} \mathrm{H}_{8.00} \mathrm{O}_{9.00}$ was determined from an average result of four analyses of bigcreekite, with $\mathrm{H}_{2} \mathrm{O}$ calculated by stoichiometry. The ideal formula for bigcreekite is $\mathrm{BaSi}_{2} \mathrm{O}_{5} \bullet 4 \mathrm{H}_{2} \mathrm{O}$. To determine the amount of $\mathrm{H}_{2} \mathrm{O}$ in the structure, crystal-structure information was needed. The results of the electron-microprobe study are given in Table 2 . Severe burn-up of the sample occurred during the electron-microprobe analyses, resulting in high weight percent totals.

The presence of $\mathrm{H}_{2} \mathrm{O}$ was confirmed by micro-infrared spectroscopy. The infrared spectrum of bigcreekite was obtained using a Bomem Michelson MB-120 Fourier-transform spectrometer with a diamond-anvil cell as a microsampling device. The spectra show absorption bands at $1634 \mathrm{~cm}^{-1}$ due to $\mathrm{H}-\mathrm{O}-\mathrm{H}$ bending and at $3260 \mathrm{~cm}^{-1}$ due to $\mathrm{O}-\mathrm{H}$ stretching, confirming the presence of $\mathrm{H}_{2} \mathrm{O}$ molecules in the structure.

\section{X-Ray CRystallography And CRystal-Structure Determination}

\section{Experimental}

The crystal used in this study is from the Esquire \#7 claim. Intensity data were collected using a Siemens $P 3$ four-circle diffractometer operated at $55 \mathrm{kV}$ and $35 \mathrm{~mA}$, with graphite-monochromatized MoK $\alpha$ radiation. The unit cell was determined using 50 reflections over the range 9.49 to $49.59^{\circ} 2 \theta$; the cell dimensions given in Table 3 , and the orientation matrix relating the crystal

TAELE 2. CHEMICAL COMPOSITION OF BIGCREEKITE

\begin{tabular}{|c|c|c|c|c|c|c|}
\hline & 러. 1 & Pt. 2 & Pt. 3 & $\mathrm{Ft} 4$ & A.yerage & |dea| \\
\hline $\mathrm{SiO} \mathrm{O}_{2} \mathrm{~W}$ & 37.59 & 39.42 & 37.44 & 39.22 & 38.16 & 34.78 \\
\hline $\mathrm{BnO}$ & 46.59 & $4 B 55$ & 50.39 & 49.97 & 48.68 & 44.37 \\
\hline $\mathrm{SrO}$ & 0.02 & 0.02 & 0.00 & 0.03 & 0.02 & 0.00 \\
\hline $\mathrm{CoO}$ & 0.00 & 0,08 & 0,04 & 0.00 & 0.03 & 0.00 \\
\hline $\mathrm{Na}_{2} \mathrm{O}$ & $0.2 \mathrm{E}$ & 0.09 & 000 & 0.07 & 0.11 & 0.00 \\
\hline $\mathrm{H}_{2} \mathrm{O}^{\circ}$ & 22,48 & 23,52 & 22.69 & 23.05 & 22.94 & 20.85 \\
\hline Total & 106.94 & 141.69 & 110.53 & 111.34 & 110.14 & 100.00 \\
\hline$S^{+}$eptu & 2.01 & 201 & 7.93 & 1.99 & 2.00 & 2.00 \\
\hline $\mathrm{Ba}^{2-}$ & 0.97 & 0.97 & 104 & 1.02 & 1.00 & 1.00 \\
\hline $\mathrm{SN}^{3+}$ & 0.00 & 0.00 & 0.00 & 0.00 & 0.00 & 0.00 \\
\hline $\mathrm{Ca}^{7+}$ & 0.00 & 0.00 & 0.00 & 0,00 & 0.00 & 0.00 \\
\hline $\mathrm{Nag}^{+}$ & 0.03 & 0.01 & 0.00 & 0.01 & 0.01 & 0.00 \\
\hline $\mathrm{H}^{*}$ & 8.00 & 8.00 & 0.00 & 0.00 & 8.00 & B.DO \\
\hline $\mathrm{O}^{2-}$ & 9.00 & 9.00 & 0.00 & 900 & 900 & 9.00 \\
\hline
\end{tabular}

Nole: Analytical results are normelized on nine anions per formula unit. - Deterimined by stoichiomelry. apris. atoms per formule unit. axes and diffractometer axes, were obtained through subsequent least-squares refinement of these reflections. Intensity data were collected in the $\theta-2 \theta$ scan mode, using 96 steps with a scan range from $\left[2 \theta\left(\mathrm{MoK} \alpha_{1}\right)-\right.$ $1.1]^{\circ}$ to $\left[2 \theta\left(\mathrm{MoK} \alpha_{2}\right)+1.1\right]^{\circ}$ and a variable scan-rate between 1.0 and $29.3 \%$ min depending on the intensity of an initial one-second count at the center of the scan range. Backgrounds were measured for half the scan time at the beginning and end of each scan. Two standard reflections were monitored every 23 reflections; there were no significant changes in their intensities during data collection. A complete sphere of reflections (9549 measurements, exclusive of standards) was collected from 3 to $60^{\circ} 2 \theta$. Fourteen strong reflections uniformly distributed with regard to $2 \theta$ were measured at $5^{\circ}$ intervals of $\Psi$ (the azimuthal angle corresponding to rotation of the crystal about its diffraction vector) from 0 to $355^{\circ}$, after the method of North et al. (1968). Twenty-seven of the 1015 reflections collected were rejected because of bad backgrounds; the remaining 988 reflections were used to calculate an absorption correction. The merging $R$ index for the $\Psi$-scan dataset decreased from $14.6 \%$ before the absorption correction to $3.6 \%$ after the absorption correction. This correction was then applied to the entire dataset; minimum and maximum transmissions were 0.36 and 0.84 , respectively. The data were also corrected for Lorentz, polarization and background effects, averaged and reduced to structure factors. Thirty-six reflections were rejected on the basis of systematic-absence violations, and 574 more were rejected because of inconsistent equivalents; of the remaining 1274 unique reflections, eight were suppressed, and 1244 were classed as observed [ $F_{\mathrm{o}}>$ $\left.4 \sigma\left(F_{\mathrm{o}}\right)\right]$.

\section{Structure solution and refinement}

The Siemens SHELXTL Version 5.03 system of programs was used throughout this study. Scattering factors for neutral atoms, f' and f" and absorption coefficients were taken from the International Tables for

\begin{tabular}{|c|c|c|c|}
\hline$a(A)$ & $5.0453(8)$ & No of $F_{0}>4 c, F_{s}$ & 1244 \\
\hline$b$ & $9.044(1)$ & ur-scan reflectlo:s & 988 \\
\hline$c$ & $18.366(5)$ & $R$ (ażIT L:hal|j|\% & $14.6-3.6$ \\
\hline$W\left(A_{1}^{\top}\right)$ & $838.0(3)$ & $\sqrt{\pi}($ merge $) \%$ & 9.6 \\
\hline Space g̣roup & Pnms $\{\#$ 62\} & $R$ lobserved]\% & 35 \\
\hline Cryst:zl size (rm) & $0.2 \div 02 \div 0.4$ & why lobsened) $\%$ & 96 \\
\hline Radinono & Mokolgrapinite & GooF & 1.3 \\
\hline No of intęnestiliẹs & 9549 & $\mu m(\operatorname{mm})\}$ & 5.04 \\
\hline No of 5 & 1274 & Cenll contenk & $4\left[\mathrm{BaSl}-\mathrm{O}_{2} \cdot 4 \mathrm{H}_{2} \mathrm{O}\right]$ \\
\hline \multicolumn{2}{|c|}{$R_{1}=\Sigma\left[\left|F_{o}\right|-\left|F_{:}\right| Y_{2}\right] F_{3} \mid$} & \multicolumn{2}{|c|}{ 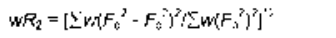 } \\
\hline \multicolumn{4}{|c|}{ 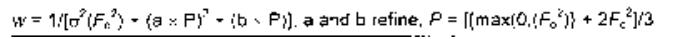 } \\
\hline
\end{tabular}


TABLE 4. ATOMIC PARAMETERS FOR BIGCREEKITE

\begin{tabular}{|c|c|c|c|c|c|c|c|c|c|c|}
\hline Site & $x$ & $y$ & $z$ & $U_{i r}$ & $U_{2}$ & $U_{\mathrm{y}}$ & $U_{1 z}$ & $U_{n, 3}$ & $U_{27}$ & $u_{0}$ \\
\hline $\mathrm{Ba}$ & $0.185+4\{4\}$ & $1 / 4$ & $0.55399[1]$ & $0.0245(2)$ & $0.0154(2)$ & $0.0084(2)$ & 0 & $0.00081(5)$ & 0 & $0.0161(1)$ \\
\hline Si & $0.1660(1)$ & $0.07197(7)$ & $0.20374(4)$ & $0.0098(3)$ & $0.0112(3)$ & $0.0054(3)$ & $-0.0001(2)$ & $0.0003(2)$ & $-0.0009(2)$ & $0.0088(2)$ \\
\hline$O_{(1)}$ & $0.3800(3)$ & $0.0146(2)$ & $0.2849(1)$ & $0.0097(6)$ & $0.0153(7)$ & $0.0148(\mathrm{~B})$ & $-0.0014(6)$ & $-0.0015(6)$ & 0.0032(B) & $0.0133(3)$ \\
\hline$O(2)$ & $0.2139(3)$ & 0 oose $(2)$ & $0.1248(1)$ & $0.0192(8)$ & $0.0187(6)$ & $0.0091(8)$ & $0.0002(6)$ & $0.0023(3)$ & $-0.0035(7)$ & $0.0157(4)$ \\
\hline$O(3)$ & $0.1700(5)$ & $1 / 4$ & $0.2039(2)$ & $0.0177(11)$ & $0.0124(11)$ & $0.0179(13)$ & 0 & $-0.0012(B)$ & 0 & $0.0159[5]$ \\
\hline OWN(4) & $0.1945(5)$ & $1 / 4$ & $0.0246(2)$ & $0.0236(14)$ & $0,0243(14)$ & $0.0171(15)$ & 0 & $0.0013(9)$ & 0 & $0.0217(6)$ \\
\hline OWu(s) & $0.2019(4)$ & $0.0410(4)$ & $0.4410(1)$ & $0.0223(11)$ & $0.0408(16)$ & $0.0162(11\}$ & $-0.004(8)$ & $0.0018(6)$ & $-0.0072(9)$ & $0.0264(6\}$ \\
\hline OW(6) & $0.254(1)$ & $1 / 4$ & $0.8448(2)$ & $0.0688(22)$ & $0.0401(14)$ & $0.0305(21)$ & 0 & $-0.0260(20)$ & 0 & $0.0395(9)$ \\
\hline
\end{tabular}

Crystallography, Volume C (1992). Miscellaneous data about collection and refinement are given in Table 3. The convention $c<a<b$ was not followed in order to facilitate comparison with the crystal structures of other Ba-silicate minerals.

The mean value of $E^{2}-1$ was found to be 0.921 , which implies a centrosymmetric space-group. Patterson techniques were used to solve the structure, which was refined in Pnma to an $R_{1}$ index of $8.9 \%$ for an isotropic displacement model. Conversion to anisotropic displacement factors for all of the atoms in the structure resulted in convergence at $R_{1}$ and $w R_{2}$ indices of 3.5 and $9.6 \%$, respectively $\left(R_{1}=3.7 \%\right.$ for all 1274 data). Addition of an isotropic extinction correction did not improve the results. The program MISSYM (LePage 1987) was used to search for missing elements of symmetry; none was detected. Positional coordinates and anisotropic and equivalent isotropic displacement factors are given in Table 4. Selected interatomic distances and angles are given in Table 5, and a bond-valence analysis is given in Table 6 . Tables listing the observed and calculated structure-factors may be obtained from the Depository of Unpublished Data, CISTI, National Research Council of Canada, Ottawa, Ontario K1A 0S2, Canada.

\begin{tabular}{|c|c|c|c|}
\hline$B a \cdot O(2) a \& O(2) b$ & $2.71002\}$ & Ol1)-Si-0[1]e & $103.80(6)$ \\
\hline$-O W(5)$ \& OWh(S) & $2.807(3)$ & $0(1)-5) \cdot 0(3)$ & $107.9(1)$ \\
\hline . Ow/6id & $2.86114\}$ & ol1e-Si-O 03$\}$ & $108.9(1)$ \\
\hline -owidie & $2868(3)$ & आ1]e-Si-O(2) & $1097(1)$ \\
\hline$-0 \mathrm{~m} / 4 \mathrm{~s}^{\prime} r$ & $2947(3)$ & $0|2|-5 ;-0 \mid 3]$ & $111.9(4)$ \\
\hline -ow(5)g \& ow (5)h & $3279(3)$ & $Q(1)-5 j-Q(2)$ & 114.2(1) \\
\hline$\angle 9 \mathrm{n}-0$ & 2.918 & $0-\mathrm{Si}-\mathrm{O}$ & 109.4 \\
\hline$S-0(2)$ & $1.584[2]$ & & \\
\hline$-0(3)$ & $1610[1]$ & & \\
\hline$-0(1) e$ & $1639(2)$ & & \\
\hline$-\infty(1)$ & $1.641(2)$ & & \\
\hline$<\mathrm{Si}-\mathrm{O}\rangle$ & 1618 & & \\
\hline
\end{tabular}

Note: $\angle M$ p denotes the mean metal-igand distance (A). Equwalent postitons: $a=x+1 / 2, y+1 / 2, z+1 / z ; b=x+1 / 2, y, z+1 / 2: c=x, y+1 / 2 z: d=z-1 / 2$

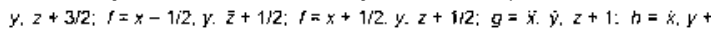
$1 / z, z+1$.

\section{DESCRIPTION OF THE STRUCTURE}

There are two distinct cation sites in the structure of bigcreekite. The atom at the $B a$ site, at special position $4 c(x, 1 / 4, z)$, is coordinated by seven $\mathrm{H}_{2} \mathrm{O}$ groups and two $\mathrm{O}$ atoms, forming a triaugmented triangular prism (Fig. 2). The $\mathrm{Ba}-\mathrm{O}$ distances range from 2.710 to 3.279 $\AA$ (mean $2.918 \AA$ ), and the $\mathrm{O}-\mathrm{Ba}-\mathrm{O}$ angles vary from
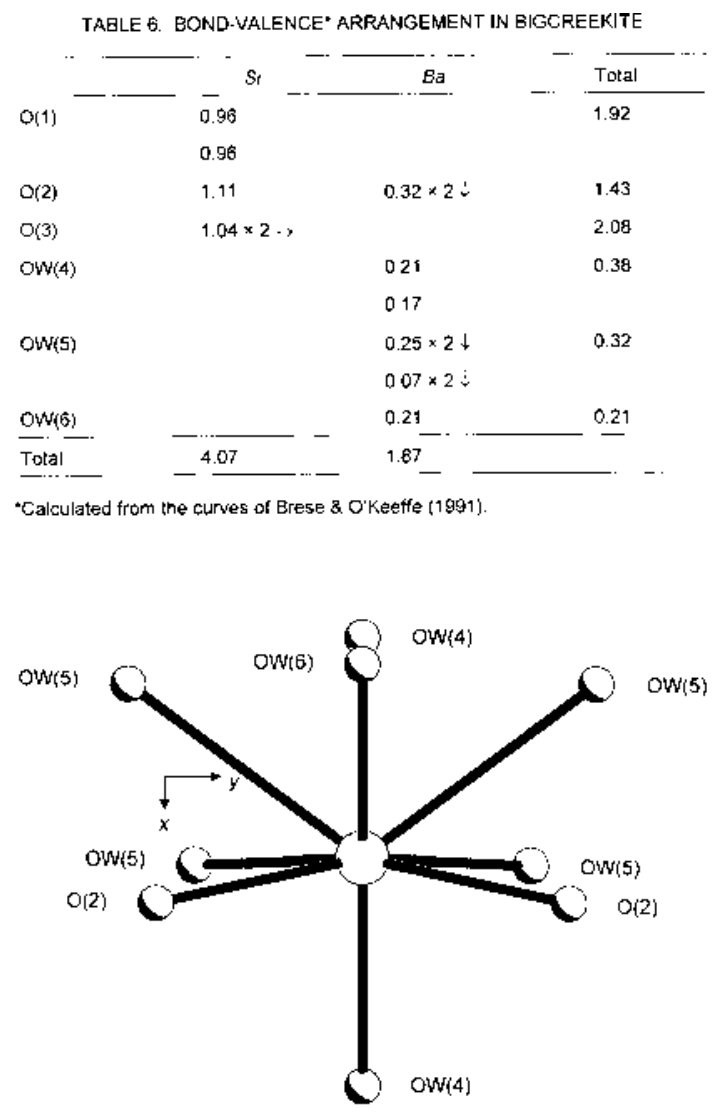

FIG. 2. Coordination of the $B a$ position in bigcreekite. 


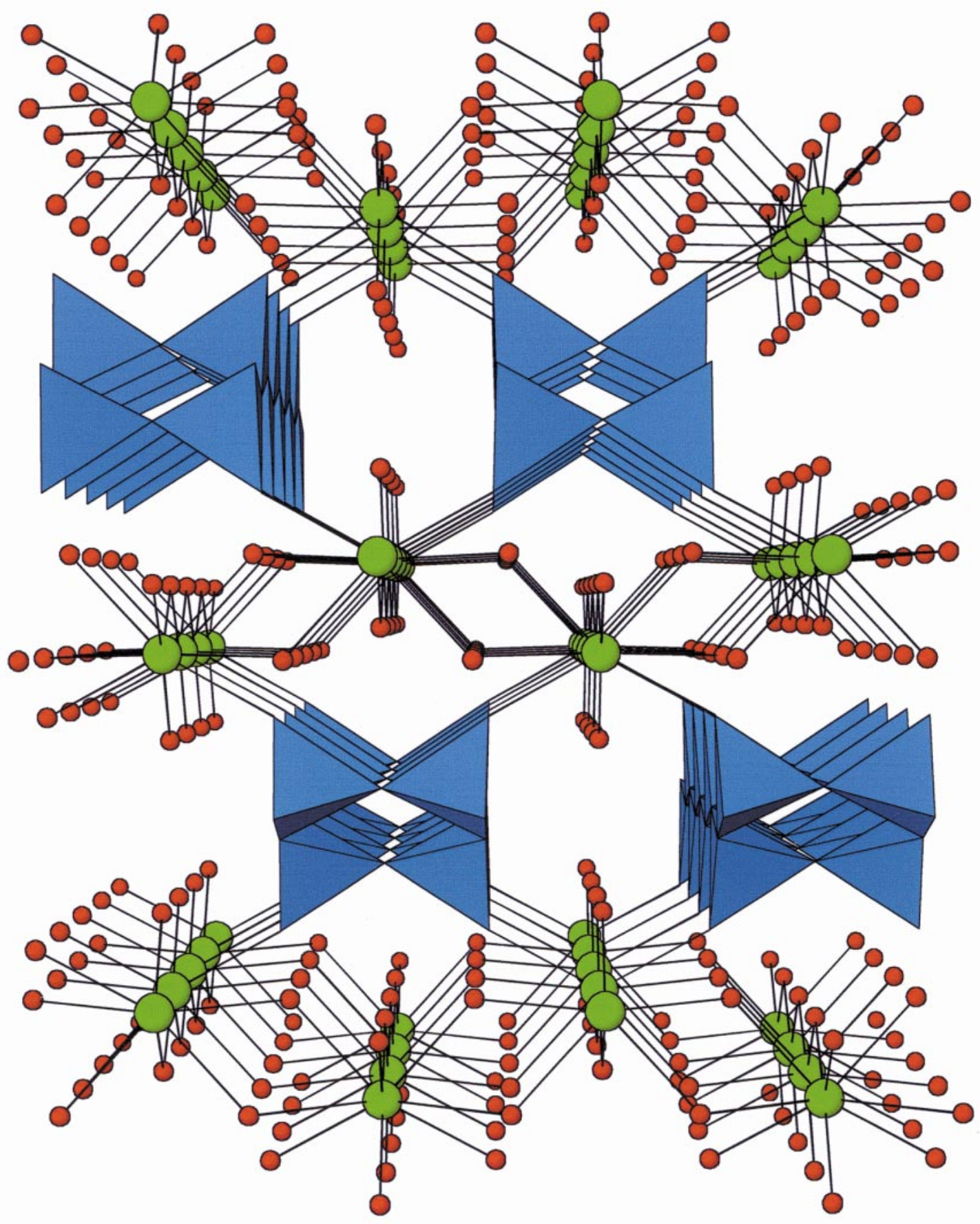

FIG. 3. Perspective drawing of the crystal structure of bigcreekite, viewed down [100] with $c$ vertical. 
53.86 to $125.43^{\circ}$ (mean $83.8^{\circ}$ ). The polyhedron volume is $44.36 \AA^{3}$. The electron-microprobe data, refined siteoccupancy, and bond-valence analysis confirm that the site is completely filled with $\mathrm{Ba}$.

The atom at the $S i$ site, at general position $8 d$, is coordinated by four $\mathrm{O}$ atoms forming a distorted tetrahedron. The $\mathrm{Si}-\mathrm{O}$ distances range from 1.584 to 1.641 $\AA$ (mean $1.618 \AA$ ), and the $\mathrm{O}-\mathrm{Si}-\mathrm{O}$ angles range from 103.80 to $114.2^{\circ}$ (mean $109.4^{\circ}$ ). The polyhedron volume is $2.17 \AA^{3}$, with a variance in the tetrahedral angle of 12.5 and a mean quadratic elongation of the tetrahedron of 1.003 . The electron-microprobe data, refined site-occupancy, and bond-valence analysis confirm that the site is completely filled with $\mathrm{Si}$.

The $\mathrm{SiO}_{4}$ tetrahedra share $\mathrm{O}(1)$ atoms to form sillimanite-like $\left[\mathrm{Si}_{2} \mathrm{O}_{5}\right]^{2-}$ chains parallel to $a$ and staggered in the $c$ direction; the $\mathrm{Si}-\mathrm{O}(1)-\mathrm{Si}$ angle is $136.1^{\circ}$. Within individual chains, all $\mathrm{O}(3)$ vertices point in the same direction parallel to $b$, but the $\mathrm{O}(2)$ vertices alternate $\pm c$. Pairs of chains are connected through corner-sharing of $\mathrm{O}(3)$ atoms to form $\left[\mathrm{Si}_{4} \mathrm{O}_{12}\right]^{8-}$ rings (Fig. 3). The $\mathrm{Si}-\mathrm{O}(3)-\mathrm{Si}$ angle is approximately linear $\left(178.8^{\circ}\right)$.

Each $\mathrm{Ba}\left(\mathrm{H}_{2} \mathrm{O}, \mathrm{O}\right)_{9}$ polyhedron shares two OW(5)OW(5) edges (3.07 $\AA$ in length) with two other $\mathrm{Ba}\left(\mathrm{H}_{2} \mathrm{O}, \mathrm{O}\right)_{9}$ polyhedra to form ribbons parallel to $b$. The ribbons are connected in the $a$ direction by corner-sharing of OW(4) groups, to form modulated sheets parallel to (001). Each $\mathrm{Ba}\left(\mathrm{H}_{2} \mathrm{O}, \mathrm{O}\right)_{9}$ polyhedron connects to two different chains of $\mathrm{SiO}_{4}$ tetrahedra through corner-sharing of $\mathrm{O}(2)$ atoms.

As shown by bond-valence analysis (Table 6), $\mathrm{OW}(4), \mathrm{OW}(5)$, and $\mathrm{OW}(6)$ are $\mathrm{H}_{2} \mathrm{O}$ complexes, and some weak hydrogen bonding may affect $\mathrm{O}(2)$. The $\mathrm{H}$ atoms are most likely located in the large channels between and parallel to the chains of $\mathrm{SiO}_{4}$ tetrahedra. Bigcreekite readily dehydrates under vacuum, with the crystals altering to a fibrous mass. The perfect cleavages $\{010\}$ and $\{001\}$ observed in bigcreekite are likely due to the channels between and parallel to the chains of $\mathrm{SiO}_{4}$ tetrahedra and the sheets of $\mathrm{Ba}\left(\mathrm{H}_{2} \mathrm{O}, \mathrm{O}\right)_{9}$ polyhedra, respectively.

\section{DisCUSSION}

Bigcreekite is a multiple-chain silicate with unbranched zweier $\left[\mathrm{Si}_{4} \mathrm{O}_{10}\right]^{4-}$ double chains (Liebau 1985). Structures with similar topologies include $\mathrm{Li}_{4}\left[\mathrm{SiGe}_{3} \mathrm{O}_{10}\right]$ and sillimanite (assuming complete $\mathrm{Al} /$ $\mathrm{Si}$ order). The only other Ba-silicate minerals with no additional cations are sanbornite, $\mathrm{BaSi}_{2} \mathrm{O}_{5}$, and krauskopfite, $\mathrm{BaSi}_{2} \mathrm{O}_{4}(\mathrm{OH})_{2} \bullet 2 \mathrm{H}_{2} \mathrm{O}$. The crystal structure of sanbornite was solved in space group Pcmn by Douglass (1958) and refined by Hesse \& Liebau (1980), and that of a high-temperature polymorph of sanbornite was described by Katscher et al. (1973) and refined by Hesse \& Liebau (1980). Both polymorphs contain zweier single chains of silicate tetrahedra parallel to $a$; the repeat distance is approximately $4.6 \AA$. The chains are linked via every second tetrahedron to form unbranched zweier $\left[\mathrm{Si}_{2} \mathrm{O}_{5}\right]^{2-}$ single layers parallel to (001). The coordination of the $\mathrm{Ba}$ atoms is nine in sanbornite, and both nine and $8+2$ occur in the high-temperature polymorph. The Ba polyhedra share edges to form layers parallel to (001).

The crystal structure of krauskopfite was solved by Coda et al. (1967). They showed that it consists of vierer single chains of $\mathrm{SiO}_{3}(\mathrm{OH})$ tetrahedra parallel to $c$. The chains are connected by sheets made up of six-membered rings of $\mathrm{Ba}_{3}(\mathrm{OH})_{2}\left(\mathrm{H}_{2} \mathrm{O}\right)_{4}$ polyhedra, oriented parallel to (100).

Although bigcreekite is not a cyclosilicate, the chains may be considered to be made up of rings of $\mathrm{SiO}_{4}$ tetrahedra. It is interesting to note that most of the cyclosilicates with $\left[\mathrm{Si}_{4} \mathrm{O}_{12}\right]^{8-}$ rings listed in Liebau (1985) contain $\mathrm{Ba}$; these include baotite, nagashimalite, taramellite, verplanckite, and synthetic $\mathrm{Na}_{2} \mathrm{BaNd}_{2}$ $\left[\mathrm{SiO}_{4} \mathrm{O}_{12}\right]\left[\mathrm{CO}_{3}\right]$. Verplanckite is known to occur at the Big Creek locality, and titantaramellite has been described from both the Big Creek and Trumbull Peak localities.

\section{ACKNOWLEDGEMENTS}

The authors thank M. Raudsepp for initial electronmicroprobe analyses, and E.A. Moffatt for the infraredabsorption spectroscopy study. The manuscript was improved by comments from J.T. Alfors, A.R. Kampf, J.A. Mandarino, and R.F. Martin. Financial support was provided by the Natural Sciences and Engineering Research Council of Canada in the form of a Research Grant to LAG, and by equipment grants from the BC Science and Technology Development Fund and the University of British Columbia.

\section{REFERENCES}

Alfors, J.T. \& PABST, A. (1984): Titanian taramellites in western North America. Am. Mineral. 69, 358-373.

Stinson, M.C., Matthews, R.A. \& Pabst, A. (1965): Seven new barium minerals from eastern Fresno County, California. Am. Mineral. 50, 314-340.

BRESE, N.E. \& O'KeEFFe, M. (1991): Bond-valence parameters for solids. Acta Crystallogr. B47, 192-197.

CodA, A., Dal Negro, A. \& Rossi, G. (1967): The crystal structure of krauskopfite. Atti Accad. Naz. Lincei, Cl. Sci. Fis., Mat. Nat., Rend. 42, 859-873.

Douglass, R.M. (1958): The crystal structure of sanbornite, $\mathrm{BaSi}_{2} \mathrm{O}_{5}$. Am. Mineral. 43, 517-536.

Dunning, G.E. \& Cooper, J.F., JR. (1999): Barium silicate minerals from Trumbull Peak, Mariposa County, California. Mineral. Rec. 30, 411-417. 
Hesse, K.-F. \& LiEBAU, F. (1980): Crystal chemistry of silicarich barium silicates. III. Refinement of the crystal structures of the layer silicates $\mathrm{Ba}_{2}\left[\mathrm{Si}_{4} \mathrm{O}_{10}\right]$ (1), (sanbornite), and $\mathrm{Ba}_{2}\left[\mathrm{Si}_{4} \mathrm{O}_{10}\right]$ (h). Z. Kristallogr. 153, 33-41.

HinthoRne, J.R. (1974): The Origin of Sanbornite and Related Minerals. Ph.D. thesis, Univ. California, Santa Barbara, California.

INTERNATIONAL TABLES FOR X-RAY CRYSTALLOGRAPHY (1992): Volume C. Kluwer Academic Publishers, Dordrecht, The Netherlands.

KAtscher, H., Bissert, G. \& Liebau, F. (1973): The crystal structure of high-temperature $\mathrm{Ba}_{2}\left[\mathrm{Si}_{4} \mathrm{O}_{10}\right]$. Z. Kristallogr. 137, 146-158.

Le Page, Y. (1987): Computer derivation of the symmetry elements implied in a structure description. J. Appl. Crystallogr. 20, 264-269.
LiEBAU, F. (1985): Structural Chemistry of Silicates: Structure, Bonding, and Classification. Springer-Verlag, New York, N.Y.

MANDARINO, J.A. (1981): The Gladstone-Dale relationship. IV. The compatibility concept and its application. Can. Mineral. 19, 441-450.

North, A.C.T., Phillips, D.C. \& Mathews, F.S. (1968): A semi-empirical method of absorption correction. Acta Crystallogr. A24, 351-359.

Received February 9, 2000, revised manuscript accepted February $14,2000$. 